Article

\title{
High Yield to 1-Propanol from Crude Glycerol Using Two Reaction Steps with Ni Catalysts
}

\author{
Martín N. Gatti, Julieta L. Cerioni, Francisco Pompeo, Gerardo F. Santori and Nora N. Nichio * \\ Centro de Investigación y Desarrollo en Ciencias Aplicadas (CINDECA) y Facultad de Ingeniería, Universidad \\ Nacional de La Plata-Consejo Nacional de Investigaciones Científicas y Técnicas (UNLP-CONICET), 47 No. 257, \\ La Plata 1900, Argentina; martin.gatti@ing.unlp.edu.ar (M.N.G.); julieta.cerioni@quimica.unlp.edu.ar (J.L.C.); \\ fpompeo@quimica.unlp.edu.ar (F.P.); santori@quimica.unlp.edu.ar (G.F.S.) \\ * Correspondence: nnichio@quimica.unlp.edu.ar; Tel.: +54-221-422-1878
}

Received: 26 April 2020; Accepted: 22 May 2020; Published: 2 June 2020

check for updates

\begin{abstract}
The objective of the present work is to achieve high yield to 1-propanol (1-POH) by crude glycerol hydrogenolysis in liquid phase and find an alternative to the use of noble metals by employing $\mathrm{Ni}$ catalysts. Two Ni catalysts with different supports, alumina $\left(\gamma-\mathrm{Al}_{2} \mathrm{O}_{3}\right)$, and a phosphorous-impregnated carbon composite (CS-P) were studied and characterized in order to determine their acid properties and metallic phases. With the $\mathrm{Ni} / \gamma-\mathrm{Al}_{2} \mathrm{O}_{3}$ catalyst, which presented small particles of metallic Ni interacting with the acid sites of the support, it was possible to obtain a complete conversion of crude glycerol with high selectivity towards 1,2-propylene glycol (1,2 PG) $(87 \%)$ at $220{ }^{\circ} \mathrm{C}$ whereas with the $\mathrm{Ni} / \mathrm{CS}-\mathrm{P}$ catalyst, the presence of AlPOx species and the $\mathrm{Ni}_{2} \mathrm{P}$ metallic phase supplied acidity to the catalyst, which promoted the $\mathrm{C}-\mathrm{O}$ bond cleavage reaction of the secondary carbon of 1,2 PG to obtain $1-\mathrm{POH}$ with very high selectivity $(71 \%)$ at $260{ }^{\circ} \mathrm{C}$. It was found that the employment of two consecutive reaction stages (first with $\mathrm{Ni} / \gamma-\mathrm{Al}_{2} \mathrm{O}_{3}$ at $220{ }^{\circ} \mathrm{C}$ and then with Ni/CS-P at $260{ }^{\circ} \mathrm{C}$ ) allows reaching levels of selectivity and a yield to 1-POH (79\%) comparable to noble metal-based catalysts.
\end{abstract}

Keywords: glycerol; hydrogenolysis; 1-propanol; Ni catalyst

\section{Introduction}

Glycerol is a by-product of biodiesel synthesis and is currently considered an important biomass resource because it can be used as a raw material to synthesize other chemical compounds that, in the past, were obtained by petrochemical methods [1-4]. Particularly, glycerol hydrogenolysis leads to the formation of glycols such as 1,2-propylene glycol (1,2-PG) [5-7] and 1,3-propylene glycol (1,3-PG) [8-10], and propanols 1-propanol (1-POH) and 2-propanol (2-POH) [11-13].

With respect to 1,2-PG, it has been widely used as a raw material in cosmetic, pharmaceutical, food, and chemical industries [14]. No less important is 1-POH, a chemical utilized as an additive in the manufacture of printing inks, antifreezes, brake fluids, and cosmetic lotions that can also be employed as a solvent in the manufacture of rubber, lacquer and essential oils [15].

As previously reported by several authors, 1,2-PG is obtained by a first dehydration stage of C-O bond cleavage reaction from glycerol molecule and a subsequent hydrogenation stage, while 1-POH can be obtained through the subsequent hydrogenolysis of 1,2-PG [16-18]. However, in the literature, there are more scientific contributions focused on glycerol hydrogenolysis to produce 1,2-PG than to produce 1-POH $[19,20]$, though the latter is also a high value-added product [21].

To obtain glycols or 1-POH, a bifunctional catalyst is required. In this reaction, the surface acid-base properties of the support play an important role. On the other hand, the choice of the metallic phase is also relevant. It has been reported that metallic phases based on noble metals such as $\mathrm{Ru}[22,23]$, 
$\mathrm{Pt}[24,25]$, and $\mathrm{Pd}[26,27]$ are very active for the hydrogenation of glycerol reaction, although they are expensive and in some cases favor undesirable $\mathrm{C}-\mathrm{C}$ bond cleavage reactions.

Bhanuchander et al. [12] tested supported Pt catalysts on AlP, TiP, ZrP, and NbP. Among all the catalysts employed, $\mathrm{Pt} / \mathrm{TiP}$ was found to be the most active one in vapor phase hydrogenolysis at $220^{\circ} \mathrm{C}$ and $0.1 \mathrm{MPa}$ of $\mathrm{H}_{2}$, obtaining total glycerol conversion and high selectivity towards 1-POH $(\sim 87 \%)$ using $10 \mathrm{wt} . \%$ glycerol solutions and $1.02 \mathrm{~h}^{-1}$ of space velocity (WHSV). These authors attributed the results obtained to the acid strength present in the sites of the TiP support and to the high dispersion of the Pt atoms (particles of average diameter $4 \mathrm{~nm}$ ). These same conclusions were reported by Priya et al. [11] with Pt catalysts supported over $\mathrm{ZrO}_{2}$ modified with phosphotungstic acid. These catalysts exhibited high selectivity towards propanols ( $\sim 98 \%$ selectivity towards 1-POH and 2-POH) with total conversion of glycerol at $230{ }^{\circ} \mathrm{C}, 0.1 \mathrm{MPa}$ of $\mathrm{H}_{2}$, using dilute glycerol solutions (between 5 and $10 \mathrm{wt} . \%$ ) and $1.02 \mathrm{~h}^{-1}$ of space velocity (WHSV).

Zhu et al. [15], employing Pt catalysts supported over $\mathrm{ZrO}_{2}$ modified with $\mathrm{HSiW}$, found that propanols can be obtained at $200^{\circ} \mathrm{C}$ and $5 \mathrm{MPa}$ of $\mathrm{H}_{2}$, with high selectivity $(\sim 80 \%)$ and total conversion of glycerol using $10 \mathrm{wt} . \%$ aqueous glycerol solutions and $0.045 \mathrm{~h}^{-1}$ of space velocity in a liquid phase continuous flow reactor. These authors attributed the performance of the catalyst to a good balance between acid sites and surface-active species for hydrogenation.

Samudrala et al. [28] investigated $\mathrm{Pd} / \mathrm{MoO}_{3}-\mathrm{Al}_{2} \mathrm{O}_{3}$ catalysts for 1-POH and 2- $\mathrm{POH}$ production. They found that the synergic interaction between $\mathrm{Pd}$ and $\mathrm{MoO}_{3}$ on the $\mathrm{Al}_{2} \mathrm{O}_{3}$ support and the acidity of the catalyst were solely responsible for the high catalytic activity. High glycerol conversion $(\sim 88 \%)$ with high selectivity to propanols ( $\sim 91 \%)$ was achieved at $210{ }^{\circ} \mathrm{C}, 0.1 \mathrm{MPa}$ of $\mathrm{H}_{2}$, and $3 \mathrm{~h}$ of reaction using $10 \mathrm{wt} . \%$ glycerol.

Ryneveld et al. [19] studied $\mathrm{Pd} / \mathrm{C}$ and $\mathrm{Ru} / \mathrm{C}$ catalysts. $\mathrm{Pd} / \mathrm{C}$ can reach $38 \%$ of glycerol conversion with $52 \%$ selectivity towards 1-POH, at $250{ }^{\circ} \mathrm{C}$ and $8 \mathrm{MPa}$ of $\mathrm{H}_{2}$ and $24 \mathrm{~h}$ of reaction. $\mathrm{Ru} / \mathrm{C}$, under the same operative conditions, can reach a $\sim 99 \%$ of glycerol conversion with low selectivity towards 1-POH ( 18\%), due to C-C cleavage bond reactions.

Catalysts based on $\mathrm{Ni}$ or $\mathrm{Cu}$ have become an interesting alternative due to their capacity for $\mathrm{C}-\mathrm{O}$ bond cleavage and their lower cost [16]. Ryneveld et al. [20] analyzed Ni supported catalysts over $\mathrm{SiO}_{2}$ and $\mathrm{Al}_{2} \mathrm{O}_{3}$. They found that $\mathrm{Ni} / \mathrm{Al}_{2} \mathrm{O}_{3}$ showed the best performance with $\sim 100 \%$ conversion of glycerol and $\sim 43 \%$ selectivity towards $1-\mathrm{POH}$ at $320{ }^{\circ} \mathrm{C}, 6 \mathrm{MPa}$ of $\mathrm{H}_{2}$, and $3 \mathrm{~h}^{-1}$ of space velocity (LHSV). The authors assigned this performance to the higher concentration of strong acid sites on the $\mathrm{Ni} / \mathrm{Al}_{2} \mathrm{O}_{3}$ compared to $\mathrm{Ni} / \mathrm{SiO}_{2}$.

In order to increase selectivity to lower alcohols, such as methanol (MeOH), ethanol (EtOH) and 1-POH, Shozi et al. modified Ni/SiO 2 and Ni/ $\mathrm{Al}_{2} \mathrm{O}_{3}$ with 1 wt.\% of Re. Among the catalysts tested, $\mathrm{Ni}-\mathrm{Re} / \mathrm{Al}_{2} \mathrm{O}_{3}$ favored the formation of $1-\mathrm{POH}$, reaching $30 \%$ yield at $325^{\circ} \mathrm{C}, 6 \mathrm{MPa}$ of $\mathrm{H}_{2}$, and $24 \mathrm{~h}$ of reaction using $60 \mathrm{wt} . \%$ glycerol in a continuous-flow fixed-bed reactor [29]. In another contribution, these authors [30] studied $\mathrm{Mo}$ and $\mathrm{W}$ catalysts supported on $\mathrm{SiO}_{2}$ and $\gamma-\mathrm{Al}_{2} \mathrm{O}_{3}$. Their work showed the best results using a Mo/SiO 2 catalyst, reaching $42 \%$ glycerol conversion with $\sim 40 \%$ selectivity towards 1-POH, at $325^{\circ} \mathrm{C}, 6 \mathrm{MPa}$ of $\mathrm{H}_{2}, 60 \mathrm{wt} . \%$ glycerol and $10 \mathrm{~h}^{-1}$ of space velocity (LHSV).

From the above, it is clear that 1-POH can be obtained through glycerol hydrogenolysis though the yields achieved are relatively lower than those of 1,2-PG. In order to increment the yield towards 1-POH, Lin et al. reported sequential two-layer catalysts in a continuous-flow fixed-bed reactor. An acidic $\mathrm{H}-\beta$ catalyst layer was packed before a Ni/ $/ \mathrm{Al}_{2} \mathrm{O}_{3}$ catalyst layer in the reactor. These sequential two-layer catalysts provided good 1-POH selectivity $(\sim 69 \%)$ with complete glycerol conversion at $220^{\circ} \mathrm{C}, 2 \mathrm{MPa}$ of $\mathrm{H}_{2}$, and $6.05 \mathrm{~h}^{-1}$ of space velocity (WHSV) [31]

A less explored aspect is the effect that the use of crude glycerol from the biodiesel industry might have. Most scientific work has employed analytical glycerol solutions within a wide range of concentrations (10-80 wt.\%). However, crude glycerol from the biodiesel industry is always found at high concentrations (70-80 wt.\%) and has impurities of a different nature [32-34]. Among those impurities, remnants of methanol and $\mathrm{NaOH}$ can come from the biodiesel synthesis [32] as well as 
$\mathrm{NaCl}$ [33] or $\mathrm{Na}_{2} \mathrm{SO}_{4}$ [34] due to the neutralization of $\mathrm{NaOH}$ with inorganic acids, such as $\mathrm{HCl}$ or $\mathrm{H}_{2} \mathrm{SO}_{4}$ respectively. Matter organic non-glycerol (MONG) such as mono, di- and triglycerides may also be present in crude glycerol [33]. In the case of $\mathrm{NaOH}$, it was reported that the concentration of $\mathrm{NaOH}$ can lead to lactic acid formation, which is a degradation product [35]. With respect to the $\mathrm{NaCl}$ salt, the presence of $\mathrm{Cl}$ - can lead to a catalyst deactivation due to the incorporation of $\mathrm{Cl}$ - over the metallic particles [33]. As regards the MONG content, reports indicate that glycerides (mono, di, or triglycerides) make the catalyst surface dirty, block active sites, and even act as coke precursors [33]. In this way, the use of crude glycerol would be an important variable to study a catalytic material for the glycerol hydrogenolysis reaction.

The objectives of the present work are to achieve high yield to 1-POH by crude glycerol hydrogenolysis in liquid phase and to find an alternative to the use of noble metals by employing $\mathrm{Ni}$ catalysts. Two Ni catalysts with different supports, alumina, and a carbon composite were studied and characterized in order to determine their acid properties and metallic phases. In this sense, the acidic properties of alumina promote the dehydration of glycerol to acetol $\left(\mathrm{AcCH}_{2} \mathrm{OH}\right)$, which is the main intermediate in the hydrogenolysis reaction. Furthermore, if there is any transformation from alumina to boehmite, due to the hydrothermal conditions of this reaction, this gives it more acidity without negatively affecting the reaction. Carbon-based supports have been widely reported in liquid phase reactions at low temperatures, with advantages associated with their hydrophobicity, stability, textural properties, as well as easy recovery of the metal phase. They can also be acidified by different techniques such as functionalization with inorganic acids [36]. In fact, in previous studies, we found that a carbon composite treated with HF generates the presence of phenolic and lactonic groups on its surface, favoring the formation of 1-POH [37].

For each catalyst, the operative reaction conditions were optimized to reach total conversion and the higher selectivity to the main product.

Taking into consideration that 1,2 PG is the intermediate compound to produce 1-POH, the possibility of employing both catalysts was analyzed, using two consecutive reaction stages.

\section{Results and Discussion}

\subsection{Characterization of Supports and Catalysts}

Figure 1 shows the $\mathrm{X}$-ray diffractograms of the supports: $\gamma-\mathrm{Al}_{2} \mathrm{O}_{3}$ and phosphorous-impregnated carbon composite (CS-P). For the $\gamma-\mathrm{Al}_{2} \mathrm{O}_{3}$ support, the main peaks are observed at $2 \theta=18.9^{\circ}$, $32.5^{\circ}, 36.9^{\circ}, 39.1^{\circ}, 45.3^{\circ}, 59.6^{\circ}$ and $66.7^{\circ}$ characteristic of this low crystallinity aluminum oxide $(\bullet)$ (JCPDS 04-0858).

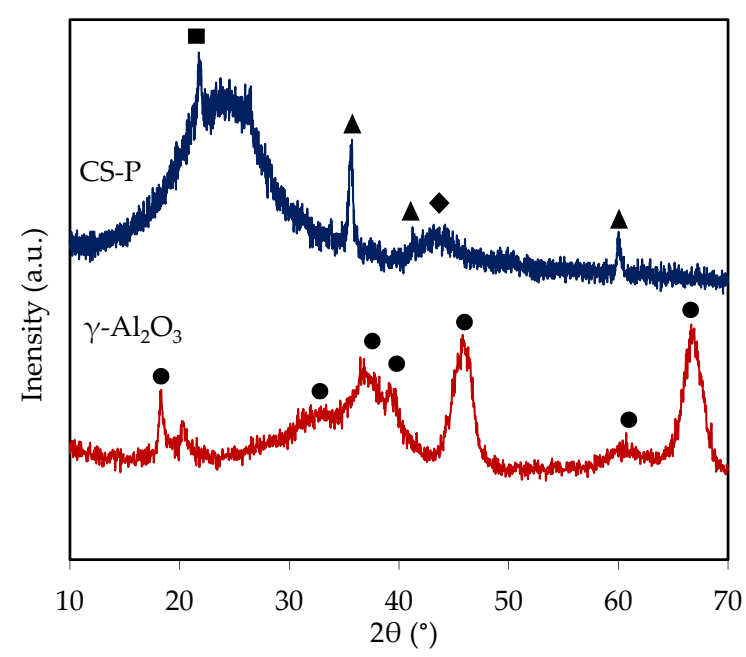

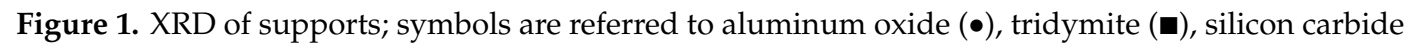
$(\Delta)$ and graphitic carbon $(\bullet)$. 
In the CS-P composite, a peak at $2 \theta=43.7^{\circ}$ can be observed that is assigned to the hexagonal phase of graphite carbon ( ) (JCPDS 25-284). The presence of graphitic carbon is due to the pyrolysis in reducing atmosphere of the phenol-formaldehyde liquid resin employed for the synthesis of the CS support (more details in Supplementary Materials). An amorphous plateau between $2 \theta=15^{\circ}$ and $30^{\circ}$ that is characteristic of amorphous silica is also observed, and a peak at $2 \theta=21.8^{\circ}$ that is assigned to the tridymite phase of silica (-) (JCPDS 18-1170). The presence of silica is due to the use of TEOS in the synthesis of the CS support. Besides, the peaks at $2 \theta=35.7^{\circ}, 41.4^{\circ}$ and $60.0^{\circ}$ can be assigned to silicon carbide ( $\mathbf{\Lambda}$ ) (JCPDS 22-1316). The formation of silicon carbide is explained due to a reaction between carbon and silica during the calcination process at $1580^{\circ} \mathrm{C}$.

Since it was not possible to observe phosphorus phases on the CS-P support, this composite was analyzed by NMR spectroscopy. Figure 2 shows the ${ }^{31} \mathrm{P}-\mathrm{NMR}$ spectra for the CS-P support that presents a band at $-27 \mathrm{ppm}$, which is associated with the presence of several orthophosphate species, generally denoted as AlPOx [38,39].

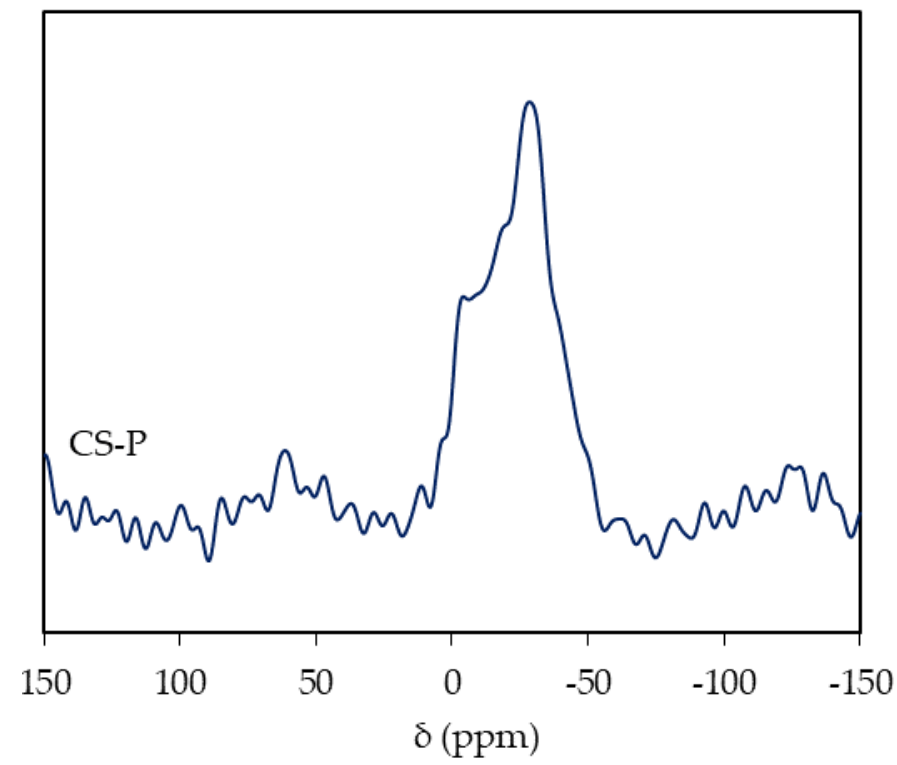

Figure 2. ${ }^{31} \mathrm{P}-\mathrm{NMR}$ spectra of the CS-P support.

Table 1 shows the textural characterization of the supports by the adsorption-desorption of $\mathrm{N}_{2}$ and the surface acid properties determined by the decomposition reaction of isopropanol (IPA) and potentiometric titration.

Table 1. Textural and acid-base properties of supports.

\begin{tabular}{|c|c|c|c|c|c|c|c|c|}
\hline \multirow{2}{*}{ Support } & \multicolumn{2}{|c|}{ BET } & \multicolumn{2}{|c|}{ Potentiometric Titration } & \multicolumn{4}{|c|}{ IPA Decomposition Reaction $\left(X_{\text {IPA }}=15 \%\right)$} \\
\hline & $\mathrm{S}_{\mathrm{BET}}{ }^{\mathrm{a}}$ & $\mathbf{V}_{\mathrm{p}} \mathbf{b}^{\mathbf{b}}$ & $\mathrm{Ei}^{\mathrm{c}}$ & NS $^{\mathrm{d}}$ & $\mathbf{T}^{\mathbf{e}}$ & $S_{\text {propylene }} \mathrm{f}$ & $S_{\text {acetone }} \mathrm{g}$ & $S_{\text {DIPE }}{ }^{h}$ \\
\hline$\gamma-\mathrm{Al}_{2} \mathrm{O}_{3}$ & 185 & 0.50 & 60 & 0.35 & 200 & 73 & 0 & 27 \\
\hline CS-P & 235 & 0.70 & 340 & 0.59 & 170 & 100 & 0 & 0 \\
\hline
\end{tabular}

${ }^{\text {a }}$ Specific surface area $\left(\mathrm{m}^{2} \mathrm{~g}^{-1}\right)^{\mathrm{b}}$ Total pore volume $\left(\mathrm{cm}^{3} \mathrm{~g}^{-1}\right)^{\mathrm{c}}$ Initial potential $(\mathrm{mV})^{\mathrm{d}}$ Total number of acid sites (mmol n-butylamine $\left.\mathrm{g}^{-1}\right)^{\mathrm{e}}$ Temperature $\left({ }^{\circ} \mathrm{C}\right)^{\mathrm{f}}$ Selectivity to propylene $(\%)^{\mathrm{g}}$ Selectivity to acetone $(\%),{ }^{\mathrm{h}}$ Selectivity to di-isopropyl ether (\%).

The adsorption-desorption isotherms of $\mathrm{N}_{2}$ for $\gamma-\mathrm{Al}_{2} \mathrm{O}_{3}$ and CS-P were of type IV, characteristic of mesoporous materials with hysteresis loops $\mathrm{H} 1$ and $\mathrm{H} 3$, respectively. Isotherms and pore size distributions are shown in Supplementary Figures S1 and S2.

Although the supports have a similar porosity around $200 \mathrm{~m}^{2} \mathrm{~g}^{-1}$, they present greater differences in their acidic surface properties. Although carbonaceous supports generally have specific surface area 
$\left(\mathrm{S}_{\mathrm{BET}}\right)$ values greater than $600 \mathrm{~m}^{2} \mathrm{~g}^{-1}$, the lower $\mathrm{S}_{\mathrm{BET}}$ in the support impregnated with $\mathrm{Al}\left(\mathrm{H}_{2} \mathrm{PO}_{4}\right)_{3}$ (CS-P) can be ascribed to a partial blocking of pores. Araujo et al. also reported that the impregnation with phosphoric acid noticeably reduced the mesoporous volume of the support [40].

The potentiometric titration technique with n-butylamine allowed determining the strength of the acid sites and the total number of acid sites present in a given solid. While the initial potential of the titration curve (Ei) indicates the maximum strength of the acid sites, the consumption of n-butylamine is related to the total number of acid sites (NS). The $\gamma-\mathrm{Al}_{2} \mathrm{O}_{3}$ and CS-P supports present Ei values of 60 and $340 \mathrm{mV}$ respectively. This indicates that the superficial acid sites are strong and very strong for $\gamma-\mathrm{Al}_{2} \mathrm{O}_{3}$ and CS-P respectively [37]. In Table 1, it can be seen that the CS-P support has a higher total number of acid sites (NS) than the $\gamma-\mathrm{Al}_{2} \mathrm{O}_{3}$ support.

The decomposition reaction of isopropanol (IPA) is known as an indirect method that allows characterizing the acid strength and type of sites of the surface of a solid. These are classified according to their ability to dehydrate and form propylene, di-isopropyl ether (DIPE) and/or acetone, or to dehydrogenize and form acetone and hydrogen.

As observed in Table 1, to achieve an IPA conversion level of $15 \%$, the CS-P support requires a temperature of $170{ }^{\circ} \mathrm{C}$, while $\gamma-\mathrm{Al}_{2} \mathrm{O}_{3}$ requires $200^{\circ} \mathrm{C}$. The lower the temperature to reach a certain level of conversion, the greater the number of surface active sites [41].

On the other hand, the selectivity analysis towards the different reaction products allows determining the nature of the surface active sites. As observed in Table 1 , the $\gamma-\mathrm{Al}_{2} \mathrm{O}_{3}$ support has a selectivity of $73 \%$ towards propylene and $27 \%$ towards DIPE, which would indicate that this material has strong Lewis acid sites. The CS-P support exhibits $100 \%$ selectivity towards propylene, indicating the presence of strong Lewis and/or Brønsted acid sites [41]. Because NMR spectroscopy shows AlPOx species, the Lewis acidity could be assigned to cations $\mathrm{Al}^{+3}$ and the Brønsted acidity to the P-OH groups, as reported by Moffat et al. [42].

As regards the Ni catalysts, Table 2 shows the results of the textural and physicochemical characterization.

Table 2. Textural and physical-chemical properties of catalysts.

\begin{tabular}{ccccccccccc}
\hline \multirow{2}{*}{ Catalyst } & AAS & \multicolumn{2}{c}{ BET } & \multicolumn{3}{c}{ Potentiometric Titration } & XRD & TEM & \multicolumn{2}{c}{ TPR } \\
\cline { 2 - 10 } & $\mathbf{N i}^{\mathbf{a}}$ & $\mathbf{S}_{\mathbf{B E T}}{ }^{\mathbf{b}}$ & $\mathbf{V}_{\mathbf{p}}{ }^{\mathbf{c}}$ & $\mathbf{E i}^{\mathbf{d}}$ & $\mathbf{N S}$ & $\mathbf{d}_{\mathbf{X R D}}{ }^{\mathbf{f}}$ & $\mathbf{d}_{\mathbf{v a}} \mathbf{g}^{\mathbf{2}}$ & $\mathbf{T}_{\mathbf{1}} \mathbf{h}^{\mathbf{h}}$ & $\mathbf{T}_{\mathbf{2}}{ }^{\mathbf{h}}$ & $\mathbf{T}_{\mathbf{3}} \mathbf{h}^{\mathbf{n}}$ \\
\hline $\mathrm{Ni} / \gamma-\mathrm{Al}_{2} \mathrm{O}_{3}$ & 4.8 & 174 & 0.50 & 36 & 0.30 & n.d. & 4 & 322 & 532 & 625 \\
$\mathrm{Ni} / \mathrm{CS}-\mathrm{P}$ & 5.2 & 395 & 0.80 & 118 & 0.50 & 11 & 12 & - & - & - \\
\hline
\end{tabular}

${ }^{a}$ Ni content $(w t . \%)^{b}$ Specific surface area $\left(\mathrm{m}^{2} \mathrm{~g}^{-1}\right)^{\mathrm{c}}$ Total pore volume $\left(\mathrm{cm}^{3} \mathrm{~g}^{-1}\right)^{\mathrm{d}}$ Initial potential $(\mathrm{mV})^{\mathrm{e}}$ Total number of acid sites $\left(\mathrm{mmol} \mathrm{n} \text {-butylamine } \mathrm{g}^{-1}\right)^{\mathrm{f}}$ Crystallite size $(\mathrm{nm})^{\mathrm{g}}$ Average particle diameter $(\mathrm{nm})^{\mathrm{h}}$ Temperature of 1st, 2nd and 3rd peak in TPR analysis $\left({ }^{\circ} \mathrm{C}\right)$.

By the AAS technique, it was determined that in both catalysts, the Ni content was very close to the nominal value ( $5 \mathrm{wt} . \%)$.

The results of the adsorption-desorption of $\mathrm{N}_{2}$ show a drop in the value of $\mathrm{S}_{\mathrm{BET}}$ for the reduced $\mathrm{Ni} / \gamma-\mathrm{Al}_{2} \mathrm{O}_{3}$ catalyst, which is due to the blocking of the pores due to the presence of $\mathrm{Ni}$. Conversely, for the Ni/CS-P catalyst, there is an increase in $\mathrm{S}_{\mathrm{BET}}$, which could be assigned to the loss of some $\mathrm{AlPO}_{\mathrm{x}}$ species of the support, during the thermal treatment in $\mathrm{H}_{2}$ flow, that were blocking the support pores. It has been reported in the literature that the thermal treatment of phosphoric acid species in carbon is employed to increase the specific area [43]. Isotherms and pore size distributions of the catalysts are shown in Supplementary Figures S1 and S2.

The results of the potentiometric titration (Table 2) indicate the preservation in the catalysts of the strong acid sites of the supports. Thus, the Ni/CS-P catalyst has a greater number of acid sites than $\mathrm{Ni} / \gamma-\mathrm{Al}_{2} \mathrm{O}_{3}$ and a higher acid strength of the sites.

Figure 3 shows the $\mathrm{X}$-ray diffractograms of the reduced catalysts. For the $\mathrm{Ni} / \gamma-\mathrm{Al}_{2} \mathrm{O}_{3}$ catalyst, a peak at $51.7^{\circ}$ is observed which corresponds to the Ni metal phase ( $\mathbf{v}$ (JCPDS 4-850). Due to the low 
intensity of this peak, it was not possible to calculate an average crystallite size (using the Scherrer equation) but this would indicate that these particles are widely dispersed.

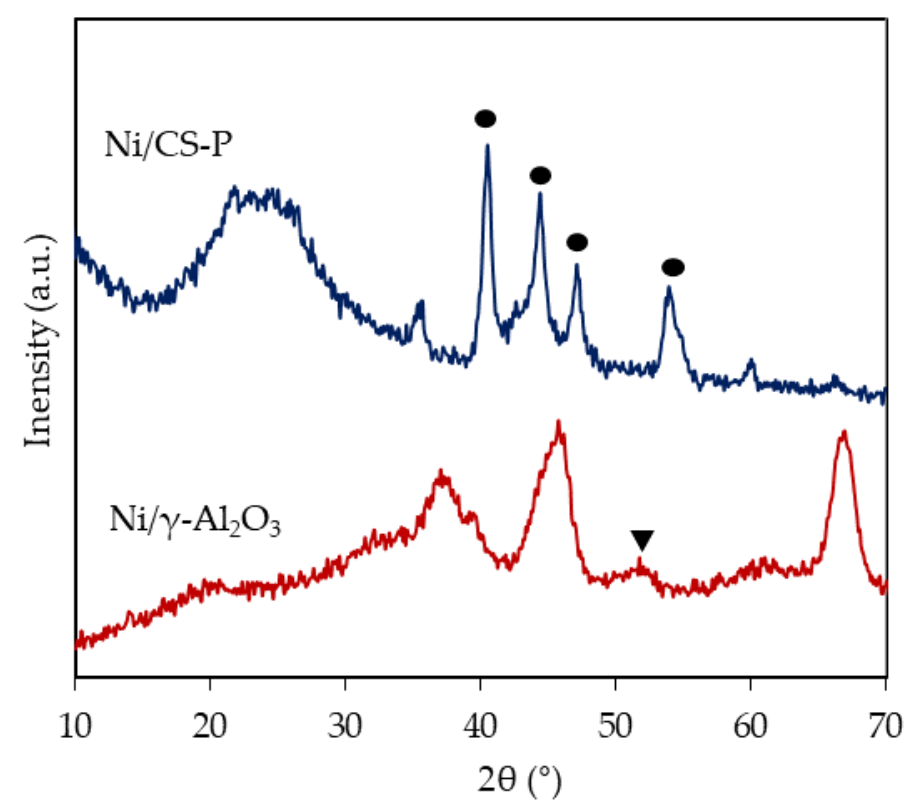

Figure 3. XRD of reduced catalysts; symbols are referred to $\mathrm{Ni}_{2} \mathrm{P}$ phase $(\bullet)$ and metallic $\mathrm{Ni}(\mathbf{\nabla})$.

In the X-ray diffractogram of the Ni/CS-P catalyst, the peaks at $2 \theta^{\circ}=40.6^{\circ}, 44.5^{\circ}, 47.1^{\circ}$ and $54.1^{\circ}$ that correspond to the $\mathrm{Ni}_{2} \mathrm{P}$ phase $(\bullet)$ can be observed (JCPDS 74-1385). Several publications have reported that in $\mathrm{Ni}$ and $\mathrm{P}$ catalysts, the $\mathrm{Ni} / \mathrm{P}$ molar ratio would determine the type of alloy formed. For $\mathrm{Ni} / \mathrm{P}$ ratios greater than 1.4, the formation of the $\mathrm{Ni}_{12} \mathrm{P}_{5}$ and $\mathrm{Ni}_{3} \mathrm{P}$ phases has been indicated, while for $\mathrm{Ni} / \mathrm{P}$ ratios less than 1 , the formation of the $\mathrm{Ni}_{2} \mathrm{P}$ phase has been reported $[44,45]$. Since the $\mathrm{Ni} / \mathrm{CS}-\mathrm{P}$ catalyst has a Ni/P molar ratio equal to 0.36 , it would be in agreement with the formation of the $\mathrm{Ni}_{2} \mathrm{P}$ phase determined by $\mathrm{XRD}$. The average crystallite size of $\mathrm{Ni}_{2} \mathrm{P}$ is about $11 \mathrm{~nm}$, obtained by the Scherrer equation, using the peak at $40.6^{\circ}$ corresponding to plane (111) of $\mathrm{Ni}_{2} \mathrm{P}$.

Since the moles of $\mathrm{P}$ with respect to $\mathrm{Ni}$ are greater, in the Ni/CS-P catalyst all $\mathrm{Ni}$ is alloyed as $\mathrm{Ni}_{2} \mathrm{P}$ and $\mathrm{P}$ unalloyed as AlPOx species, even though it was not possible to detect these latter species by XRD. While AlPOx species were detected in the support by NMR, it was not possible to apply this technique in the catalyst due to the magnetic properties of Ni.

Figure 4 shows the TEM images and the particle size distribution for the reduced catalysts. For the $\mathrm{Ni} / \gamma-\mathrm{Al}_{2} \mathrm{O}_{3}$ catalyst, the histogram shows a narrow distribution with particle sizes between 3 and $5 \mathrm{~nm}$, while the Ni/CS-P catalyst has a wider distribution, with particles from 3 to $21 \mathrm{~nm}$. Table 2 shows the average particle diameter values, where $\mathrm{Ni} / \gamma-\mathrm{Al}_{2} \mathrm{O}_{3}$ catalyst has an average diameter of $4 \mathrm{~nm}$. In contrast, the Ni/CS-P catalyst has an average diameter of $12 \mathrm{~nm}$, which is a value very similar to the crystallite size determined by XRD.

The TPR results are summarized in Table 2. As observed, the $\mathrm{Ni} / \gamma-\mathrm{Al}_{2} \mathrm{O}_{3}$ catalyst has three characteristic peaks. The first of them at $322{ }^{\circ} \mathrm{C}$ indicates the presence of low interaction $\mathrm{NiO}$ with the support. The second peak, at $532{ }^{\circ} \mathrm{C}$, would indicate the reduction of $\mathrm{Ni}^{+2}$ ions incorporated in the octahedral vacancies of $\gamma-\mathrm{Al}_{2} \mathrm{O}_{3}$. Finally, the third peak at $625^{\circ} \mathrm{C}$ indicates the reduction of $\mathrm{Ni}^{+2}$ with high interaction with the support $[46,47]$. TPR peaks assigned to nickel oxides that are not completely integrated in the spinel structure, but have a certain degree of interaction with the support, were observed at temperatures between 500 and $600{ }^{\circ} \mathrm{C}$ [48].

As we have indicated, Ni/CS-P was directly activated in $\mathrm{H}_{2}$ flow $\left(50 \mathrm{~cm}^{3} \mathrm{~min}^{-1}\right)$ at $400{ }^{\circ} \mathrm{C}$ during $90 \mathrm{~min}$, so the TPR analysis would allow to verifying the reduction of the metal phase. Indeed, no peak was observed, indicating that the activation method was effective to reduce all the Ni precursor. 

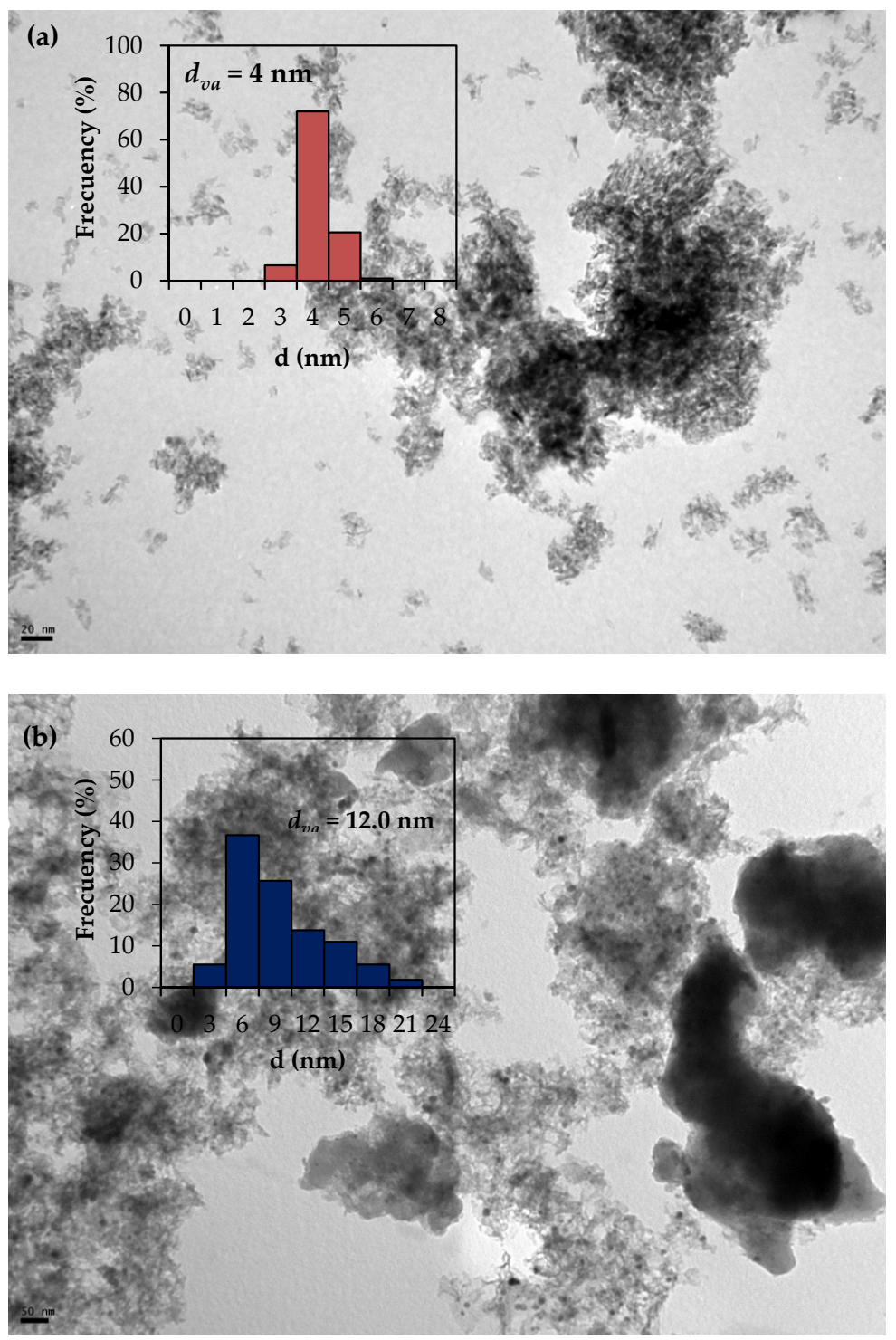

Figure 4. TEM micrographs and particle size distribution of catalysts: (a) $\mathrm{Ni} / \gamma-\mathrm{Al}_{2} \mathrm{O}_{3}$ (b) $\mathrm{Ni} / \mathrm{CS}-\mathrm{P}$.

\subsection{Catalytic Activity}

The catalytic activity tests were carried out using both technical grade glycerol (99\% Cicarelli) and crude glycerol (Oleomud). The composition of this crude glycerol ( 79 wt.\%) is shown in Table 3 . This raw material contains $\mathrm{MeOH}$ and MONG from the biodiesel manufacturing process. The MONG content includes $\mathrm{MeOH}$, mono-, di-, triglycerides, etc. The ash content is mainly due to the presence of $\mathrm{Na}^{+}$salts produced during the neutralization of the $\mathrm{NaOH}$ catalyst with acid.

Table 3. Characterization of crude glycerol.

\begin{tabular}{cc}
\hline Parameter & Value \\
\hline $\mathrm{pH}$ & 6.0 \\
Density & 1.257 \\
Glycerol content (wt.\%) & 79.3 \\
Methanol content (wt.\%) & 2.0 \\
MONG (wt.\%) & 6.7 \\
Water content (wt.\%) & 11.0 \\
Ash content (wt.\%) & 3.0 \\
\hline
\end{tabular}


Catalytic activity results in the glycerol hydrogenolysis reaction are shown in Table 4.

Table 4. Glycerol hydrogenolysis.

\begin{tabular}{|c|c|c|c|c|c|c|c|c|c|c|c|c|c|}
\hline \multirow{2}{*}{ Test } & \multirow{2}{*}{$\begin{array}{c}\text { Gly } \\
\text { (wt.\%) }\end{array}$} & \multirow{2}{*}{$\mathrm{T}\left({ }^{\circ} \mathrm{C}\right)$} & \multirow{2}{*}{$t(h)$} & \multirow{2}{*}{$X(\%)$} & \multicolumn{8}{|c|}{ Selectivity (\%) } & \multirow{2}{*}{$\mathrm{CB}^{\mathrm{c}}(\%)$} \\
\hline & & & & & Gases & $\mathrm{MeOH}$ & EtOH & $\mathrm{AcO}$ & 1-POH & $\mathrm{AcCH}_{2} \mathrm{OH}$ & EG & $1,2-\mathrm{PG}$ & \\
\hline \multicolumn{13}{|c|}{$\mathrm{Ni} / \gamma-\mathrm{Al}_{2} \mathrm{O}_{3}$ catalyst } & \\
\hline 1 & 10 & 200 & 2 & 10.0 & 0.0 & 1.2 & 3.6 & 0.0 & 0.4 & 0.5 & 19.2 & 75.1 & 93 \\
\hline 2 & 10 & 220 & 2 & 22.0 & 1.8 & 0.9 & 6.8 & 0.0 & 0.0 & 0.3 & 12.6 & 77.6 & 95 \\
\hline 3 & 10 & 260 & 2 & 44.7 & 20.1 & 10.7 & 20.4 & 5.7 & 6.5 & 0.2 & 26.8 & 9.6 & 96 \\
\hline 4 & 80 & 220 & 2 & 40.0 & 1.3 & 0.4 & 5.2 & 0.0 & 0.3 & 2.1 & 4.0 & 86.7 & 96 \\
\hline 5 & 80 & 220 & 5 & 100.0 & 3.0 & 0.7 & 4.0 & 1.0 & 1.2 & 0.2 & 6.8 & 83.0 & 97 \\
\hline 6 & $80^{\mathrm{a}}$ & 220 & 5 & 100.0 & 3.2 & 0.5 & 2.4 & 0.1 & 0.1 & 0.0 & 6.7 & 87.0 & 97 \\
\hline \multicolumn{13}{|c|}{$\mathrm{Ni} / \mathrm{CS}-\mathrm{P}$ catalyst } & \\
\hline 7 & 10 & 220 & 2 & 4.9 & 0.5 & 0.1 & 1.0 & 0.3 & 19.3 & 0.8 & 0.0 & 78.0 & 96 \\
\hline 8 & 30 & 260 & 2 & 37.9 & 1.5 & 0.3 & 4.4 & 19.8 & 64.5 & 5.3 & 0.0 & 4.2 & 96 \\
\hline 9 & 80 & 260 & 2 & 45.1 & 1.3 & 0.4 & 4.0 & 22.0 & 67.0 & 4.0 & 0.0 & 1.3 & 96 \\
\hline 10 & $80^{\mathrm{a}}$ & 260 & 5 & 100.0 & 1.1 & 0.1 & 3.7 & 23.0 & 71.0 & 1.0 & 0.0 & 0.0 & 97 \\
\hline 11 & $80^{\mathrm{b}}$ & 260 & 2 & 100.0 & 1.5 & 0.0 & 1.1 & 2.3 & 91.0 & 4.4 & 0.0 & 0.0 & 97 \\
\hline \multicolumn{13}{|c|}{$\begin{array}{l}\mathrm{Ni} / \gamma-\mathrm{Al}_{2} \mathrm{O}_{3} \text { catalyst }+\mathrm{Ni} / \mathrm{CS}-\mathrm{P} \text { catalyst } \\
\text { Two consecutive reaction tests: } \\
-\mathrm{Al}_{2} \mathrm{O}_{3} \text { catalyst followed by } 2 \mathrm{~h} \text { at } 260^{\circ} \mathrm{C} \text { with Ni/CS-P catalyst }\end{array}$} & \\
\hline 12 & $80^{a}$ & $220-260$ & 7 & 100.0 & 6.0 & 1.4 & 4.5 & 2.4 & 79.3 & 0.0 & 6.5 & 0.0 & 97 \\
\hline
\end{tabular}

The reaction products in liquid phase that were identified and quantified were the following: from $\mathrm{C} 1$ : methanol $(\mathrm{MeOH})$, from $\mathrm{C} 2$ : ethanol $(\mathrm{EtOH})$, ethylene glycol (EG), from $\mathrm{C} 3$ : acetone $(\mathrm{AcO})$, 1-propanol (1-POH), acetol $\left(\mathrm{AcCH}_{2} \mathrm{OH}\right)$, and 1,2-propylene glycol (1,2-PG). The main gaseous products identified were $\mathrm{CO}_{2}$ and $\mathrm{CH}_{4}$.

The results of Tests $1-6$ were obtained by employing the $\mathrm{Ni} / \gamma-\mathrm{Al}_{2} \mathrm{O}_{3}$ catalyst. It can be seen that with this catalyst it was not possible to obtain 1-POH as the main product. However, the results in Table 4 indicate that, when the temperature is below $260^{\circ} \mathrm{C}$, the main product of glycerol hydrogenolysis is $1,2-\mathrm{PG}$ (Tests 1,2 , and $4-6$ ).

At $260{ }^{\circ} \mathrm{C}$ (Test 3), it can be observed that there is a strong increase in the products of $\mathrm{C} 1$ and $\mathrm{C} 2$ (Gases $\left(\mathrm{CH}_{4}\right.$ and $\left.\mathrm{CO}_{2}\right), \mathrm{MeOH}, \mathrm{EtOH}$ and $\mathrm{EG}$ ), which shows the greater contribution of the $\mathrm{C}-\mathrm{C}$ bond cleavage reactions. The $\mathrm{Ni} / \gamma-\mathrm{Al}_{2} \mathrm{O}_{3}$ catalyst has widely dispersed $\mathrm{Ni}^{0}$ particles with average sizes of $4 \mathrm{~nm}$, and this would promote $\mathrm{C}-\mathrm{C}$ bond cleavage reactions.

The selectivity towards 1,2-PG reaches its maximum value $(77.6 \%)$ at the temperature of $220^{\circ} \mathrm{C}$ (Test 2). Similarly, Marinoiu et al. employed a Ni/SiO${ }_{2}-\mathrm{Al}_{2} \mathrm{O}_{3}$ catalyst in the range $170-250{ }^{\circ} \mathrm{C}$ at 1.5 MPa of $\mathrm{H}_{2}$ and found that the yield to 1,2-PG reaches a maximum at $200{ }^{\circ} \mathrm{C}$, due to a good balance between conversion and selectivity [49]. In this sense, Menchavez et al. employed a $\mathrm{Ni} / \mathrm{CeO}_{2}-\mathrm{MgO}$ catalyst and reported that 1,2-PG selectivity was optimal in the range $200-215^{\circ} \mathrm{C}$ at $6 \mathrm{MPa}$ of $\mathrm{H}_{2}$, due to a balance between dehydration and hydrogenation reactions [50].

Furthermore, Long et al. used a Ni catalyst supported on a sepiolite modified with $\mathrm{WO}_{3}$ and reported that at temperatures higher than $200{ }^{\circ} \mathrm{C}$ the selectivity to EG increases due to C-C bond cleavage reactions [51].

From Table 4, the results at $220^{\circ} \mathrm{C}$ can be compared with different concentrations of glycerol (Tests 2 and 4), where it is observed that the level of conversion and selectivity improves with the lower content of water in the reaction mixture. Dasari et al. reported that with a $\mathrm{Cu}_{-}-\mathrm{Cr}_{2} \mathrm{O}_{4}$ catalyst, the glycerol conversion increases from $33 \%$ to $69 \%$, if the water content decreases from $80 \mathrm{wt} . \%$ to $0 \mathrm{wt} . \%$ (at $200{ }^{\circ} \mathrm{C}, 1.4 \mathrm{MPa}$ of $\mathrm{H}_{2}$ and $24 \mathrm{~h}$ of reaction) [16]. Menchavez et al. employed a $\mathrm{Ni} / \mathrm{CeO}_{2}-\mathrm{MgO}$ catalyst and reported an increase in glycerol conversion from $43 \%$ to $80 \%$ when the water content declined from $40 \mathrm{wt} . \%$ to $0 \mathrm{wt} . \%$ (at $215^{\circ} \mathrm{C}, 6.9 \mathrm{MPa}$ of $\mathrm{H}_{2}$ and $24 \mathrm{~h}$ of reaction) [50]. 
In addition, in Table 4 it can be seen that using a glycerol solution (99\% Cicarelli) at $80 \mathrm{wt} . \%$ and $220{ }^{\circ} \mathrm{C}$ (Test 5), it is possible to obtain total glycerol conversion with a 1,2-PG selectivity of 83\%, after $5 \mathrm{~h}$ of reaction, which implies a yield towards 1,2-PG of $83 \%$. This yield is superior to the ones reported in the literature for Ni-Raney $(68.8 \%)$ and $\mathrm{Ni} / \mathrm{NaX}(69.6 \%)$ catalysts $[52,53]$.

The results of the hydrogenolysis of crude glycerol (79 wt. \% Oleomud) employing the $\mathrm{Ni} / \gamma-\mathrm{Al}_{2} \mathrm{O}_{3}$ catalyst (Test 6) show that the total conversion of glycerol is also achieved with a selectivity towards 1,2-PG of $87 \%$. The quality of this raw material, which contains impurities such as $\mathrm{MeOH}$ and $\mathrm{Na}^{+}$salts, slightly affects the results and this presence could have a positive effect. Feng et al. [54] determined that the addition of $\mathrm{Li}, \mathrm{Na}$, and $\mathrm{K}$ bases to the reaction medium improves the conversion of glycerol following the order: $\mathrm{Li}^{+}>\mathrm{Na}^{+}>\mathrm{K}^{+}$. With respect to $\mathrm{MeOH}$, its presence in the reaction medium has been reported to be beneficial due to its $\mathrm{H}_{2}$ donor capacity [55].

The second part of Table 4 (Tests 7-11) shows the results of the glycerol hydrogenolysis reaction using the Ni/CS-P catalyst. Results obtained at $220^{\circ} \mathrm{C}$ with a $10 \mathrm{wt} . \%$ glycerol aqueous solution (Test 7) show that $\mathrm{Ni} / \mathrm{CS}-\mathrm{P}$ catalyst is much less active than $\mathrm{Ni} / \gamma-\mathrm{Al}_{2} \mathrm{O}_{3}$ catalyst ( $5 \%$ vs. $22 \%$ conversion), which could be due to the greater metallic dispersion of $\mathrm{Ni} / \gamma-\mathrm{Al}_{2} \mathrm{O}_{3}$. However, in the tests carried out at higher temperatures and higher glycerol concentrations, it is possible to observe that the $\mathrm{Ni} / \mathrm{CS}-\mathrm{P}$ catalyst does not favor C-C cleavage reactions, and the selectivity to $\mathrm{C} 3$ products of glycerol hydrogenolysis is very high. The results of Tests $8-10$ show that, with this catalyst, it is possible to obtain 1-POH as the main product of glycerol hydrogenolysis and the main byproduct is $\mathrm{AcO}$. The presence of $\mathrm{AcO}$ is explained precisely by the high capacity of $\mathrm{C}-\mathrm{O}$ bond cleavage of this catalyst.

As reported [16-18], 1,2-PG is the intermediate to form 1-POH and both are the main products of glycerol hydrogenolysis. This is corroborated with the results of Test 11 (Table 4) carried out with an 1,2-PG aqueous solution at $80 \mathrm{wt} . \%$, in which a selectivity towards 1-POH greater than $90 \%$ is obtained and there is a very small amount of $\mathrm{AcO}$ if compared to the glycerol-fed reaction.

The presence of strong acid sites in the Ni/CS-P catalyst would favor the C-O bond cleavage reactions of the secondary carbon, promoting the formation of 1-POH [37]. On the other hand, the results obtained by XRD evidenced the presence of $\mathrm{Ni}_{2} \mathrm{P}$ in the $\mathrm{Ni} / \mathrm{CS}-\mathrm{P}$ catalyst. In the literature, it has been reported that the formation of a NiP alloy provokes an increment in the electrophilicity of $\mathrm{Ni}$ sites due to the charge transfer from nickel to phosphorous [56,57]. This property facilitates the adsorption of the $\mathrm{O}$ atom of the $\mathrm{C}-\mathrm{O}$ bond, subsequently promoting the $\mathrm{C}-\mathrm{O}$ bond cleavage reactions. This tendency increases in the sequence $\mathrm{Ni}_{3} \mathrm{P}<\mathrm{Ni}_{12} \mathrm{P}_{5}<\mathrm{Ni}_{2} \mathrm{P}$, indicating that for $\mathrm{Ni}_{2} \mathrm{P}$ the activity to $\mathrm{C}-\mathrm{O}$ bond cleavage reactions is the highest among the different nickel phosphides [58]. With respect to the low contents of $\mathrm{C} 1$ and $\mathrm{C} 2$ reaction products, it was also found that $\mathrm{Ni}_{2} \mathrm{P}$ has a much lower activity for the $\mathrm{C}-\mathrm{C}$ bond cleavage than $\mathrm{Ni}^{0}[58,59]$. Furthermore, the Ni/CS-P catalyst has particles with an average size of $12 \mathrm{~nm}$, which is also a disadvantage for $\mathrm{C}-\mathrm{C}$ bond cleavage reactions.

At $260{ }^{\circ} \mathrm{C}$ and after $5 \mathrm{~h}$ of reaction (Test 10), a yield to $1-\mathrm{POH}$ of $71 \%$ can be obtained, comparable with other catalytic systems reported in the literature such as $\mathrm{Pt} / \mathrm{Zr}_{0.7} \mathrm{Al}_{0.3} \mathrm{O}_{\mathrm{y}}$ [13], and this is a yield superior to that obtained with $\mathrm{Ni} / \mathrm{SiO}_{2}$ and $\mathrm{Ni} / \mathrm{Al}_{2} \mathrm{O}_{3}$ [20], $\mathrm{Pd} / \mathrm{MoO}_{3}-\mathrm{Al}_{2} \mathrm{O}_{3}$ [28], $\mathrm{Pt} / \mathrm{HSiW}-\mathrm{Al}_{2} \mathrm{O}_{3}$ [21], and $\mathrm{Pt} / \mathrm{PTA}-\mathrm{ZrO}_{2}$ [11].

To combine the greater catalytic activity of both catalysts, $\mathrm{Ni} / \gamma-\mathrm{Al}_{2} \mathrm{O}_{3}$ and $\mathrm{Ni} / \mathrm{CS}-\mathrm{P}$, to obtain $1,2-\mathrm{PG}$ and 1-POH respectively, we proposed the reaction in two consecutive steps. In this way, we sought to increase the $1-\mathrm{POH}$ yield above $71 \%$ which was the maximum that could be obtained with the $\mathrm{Ni} / \mathrm{CS}-\mathrm{P}$ catalyst.

In the first reaction step, the crude glycerol hydrogenolysis reaction was carried out in order to maximize the yield to $1,2-\mathrm{PG}$, using the $\mathrm{Ni} / \gamma-\mathrm{Al}_{2} \mathrm{O}_{3}$ catalyst (Test 6 ). The second stage was carried out with the reaction products obtained from the first stage this time using the Ni/CS-P catalyst (Test 12). The gaseous products (such as $\mathrm{CH}_{4}, \mathrm{CO}_{2}$ ) produced in the first stage are the only reaction products that are lost because it is necessary to open the reactor to proceed with the replacement of the catalyst.

To calculate the selectivity to gaseous products reported in Test 12 , the moles of gaseous products from the first reaction step were considered (Test 6). 
As observed (Table 4), after the second reaction stage a 1-POH yield of $79.3 \%$ is achieved (Test 12). Considering both reaction steps, the yield at $1-\mathrm{POH}$ was comparable to that of $\mathrm{Pd} / \mathrm{CoO}$ catalysts $(\sim 80 \%)[26]$.

\section{Materials and Methods}

\subsection{Synthesis of Supports and Catalysts}

Commercial $\gamma-\mathrm{Al}_{2} \mathrm{O}_{3}(99.99 \%$, Dytech, Corporation Ltd., Sheffield, UK) and a carbonaceous-based composite were used as supports.

The carbonaceous-based composite was synthetized using the gelling property of TEOS (SILBOND 40-AKZO Chemicals (Buenos Aires, Argentina) in ethanol to include a phenol-formaldehyde liquid resin (RL 43003, ATANOR, Santa Fe, Argentina) in its structure. The Supplementary Materials describe the preparation method used. This material was then modified by impregnation with an $\mathrm{Al}\left(\mathrm{H}_{2} \mathrm{PO}_{4}\right)_{3}$ aqueous solution Sigma-Aldrich (St. Louis, MI, USA). The concentration of $\mathrm{P}$ in the solution was calculated so as to obtain $7 \mathrm{wt} . \% \mathrm{P}$ in the final solid. Finally, the solid was dried at $120^{\circ} \mathrm{C}$ for $12 \mathrm{~h}$ and calcined at $400{ }^{\circ} \mathrm{C}$ for $30 \mathrm{~min}$ (heating rate of $10^{\circ} \mathrm{C} \mathrm{min}^{-1}$ ). Thus, this support was denoted as CS-P.

The $\mathrm{Ni} / \gamma-\mathrm{Al}_{2} \mathrm{O}_{3}$ catalyst was prepared by incipient wetness impregnation employing $\mathrm{Ni}\left(\mathrm{NO}_{3}\right)_{3} \cdot 6 \mathrm{H}_{2} \mathrm{O}$ (Sigma-Aldrich), while the Ni/CS-P catalyst was prepared using $\mathrm{Ni}\left(\mathrm{CH}_{3} \mathrm{COO}\right)_{2} \cdot 4 \mathrm{H}_{2} \mathrm{O}$ in order to decompose this nickel precursor at a lower temperature so as to avoid the gassing of the carbonaceous support.

The concentration of $\mathrm{Ni}$ in the solution was calculated so as to obtain $5 \mathrm{wt} . \% \mathrm{Ni}$ in the final solid. The catalysts were dried at $120{ }^{\circ} \mathrm{C}$ during $12 \mathrm{~h}$. Ni/ $\gamma-\mathrm{Al}_{2} \mathrm{O}_{3}$ was calcined in stagnant air at $550{ }^{\circ} \mathrm{C}$ for $90 \mathrm{~min}$ (heating rate of $10^{\circ} \mathrm{C} \mathrm{min}^{-1}$ ) and activated in $\mathrm{H}_{2}$ flow $\left(50 \mathrm{~cm}^{3} \mathrm{~min}^{-1}\right)$ at $550{ }^{\circ} \mathrm{C}$ for $90 \mathrm{~min}$ (heating rate of $\left.10^{\circ} \mathrm{C} \mathrm{min}^{-1}\right)$. Ni/CS-P was directly activated in $\mathrm{H}_{2}$ flow $\left(50 \mathrm{~cm}^{3} \mathrm{~min}^{-1}\right)$ at $400{ }^{\circ} \mathrm{C}$ for

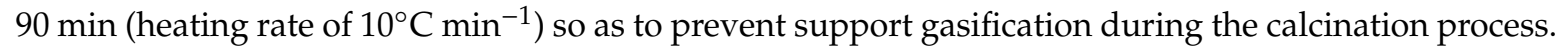

\subsection{Characterization of Supports and Catalysts}

The adsorption-desorption measurements were carried out employing $\mathrm{N}_{2}$ at $-196^{\circ} \mathrm{C}$ for the textural characterization. A Micromeritics ASAP 2020 equipment (Micromeritics Instrument Corporation, Norcross, GA, USA) was employed for the specific surface measurements and micro and mesoporous characterization. The samples were pretreated under vacuum in two 1-h stages at $100{ }^{\circ} \mathrm{C}$ and $300^{\circ} \mathrm{C}$, respectively.

The X-ray diffractograms were recorded on a Philips 1729 powder diffractometer, using $\mathrm{CuK} \alpha$ radiation $(\lambda=1.5418 \AA$, intensity $=20 \mathrm{~mA}$, and voltage $=40 \mathrm{kV})$. Spectra were collected in the range $2 \theta=10-70^{\circ}$. The crystallite sizes $\left(\mathrm{d}_{\mathrm{XRD}}\right)$ in the reduced samples were calculated using the Scherrer equation:

$$
d_{X R D}=\frac{K \times \lambda}{B \times \cos (\theta)}
$$

where $K$ was taken as 0.90 and $B$ was the full width of the diffraction line at half maximum intensity.

The solid-state NMR experiments were performed at room temperature in a $7 \mathrm{~T}$ Bruker Avance II-300 spectrometer (Billerica, MA, USA) equipped with a 4-mm MAS probe. The operating frequency for ${ }^{31} \mathrm{P}$ was 121.5 . $\mathrm{AlPO}_{4}$ was used as an external reference. ${ }^{31} \mathrm{P} 1 \mathrm{D}$ spectra were recorded using a $\pi / 2$ pulse $(4.8 \mu \mathrm{s})$ and a $30 \mathrm{~s}$ delay between two pulses. The spinning rate for the samples was $10 \mathrm{kHz}$.

The potentiometric titrations were performed employing $0.05 \mathrm{~g}$ of sample suspended in acetonitrile (Merck KGaA, Darmstadt, Germany) previously stirred for $3 \mathrm{~h}$. The titrations were suspended with solutions of n-butylamine $0.05 \mathrm{M}$ in acetonitrile, employing a Metrohm 794 Basic potentiometric titrator with a double junction electrode.

The acid-base properties of the supports were determined by the isopropanol (IPA) decomposition test reaction and the potentiometric titration technique. The IPA decomposition test reaction was 
carried out in a continuous flow reactor at atmospheric pressure between 120 and $350{ }^{\circ} \mathrm{C}$, employing an IPA flow (4.5\%) in helium $\left(40 \mathrm{~cm}^{3} \mathrm{~min}^{-1}\right)$.

The $\mathrm{Ni}$ content in the samples was determined by atomic absorption spectrometry (Spectrophotometer AA-6650 Shimadzu, Tokyo, Japan) employing an IL Model 457 spectrometer with single channel and single beam.

Temperature-programmed reduction experiments (TPR) were carried out using conventional equipment. Samples were heated from room temperature up to $800^{\circ} \mathrm{C}$ with a heating rate of $10^{\circ} \mathrm{C} \mathrm{min}^{-1}$ in a mixture of $\mathrm{H}_{2} / \mathrm{N}_{2}\left(1 / 9\right.$ ratio) with a flow of $50 \mathrm{~cm}^{3} \mathrm{~min}^{-1}$. The $\mathrm{H}_{2}$ uptake was calculated using a thermal conductivity detector (TCD) previously calibrated.

Images were obtained by electronic transmission microscopy with a TEM JEOL $100 \mathrm{C}$ instrument (JEOL Ltd., Tokyo, Japan) operating at $200 \mathrm{kV}$. The samples were suspended in 2-propanol and sonicated in an ultrasonic bath during $10 \mathrm{~min}$ prior to analysis. In order to estimate average diameter volume/area $\left(\mathrm{d}_{\mathrm{va}}\right)$, the particles were considered spherical and the following expression was used for the calculation:

$$
d_{v a}=\frac{\sum n_{i} \times d_{i}^{3}}{\sum n_{i} \times d_{i}^{2}}
$$

where $n_{i}$ is the number of particles with diameter $d_{i}$. The particle size distribution histograms were obtained from micrographs employing the bright field technique.

\subsection{Crude Glycerol Characterization}

Crude glycerol was supplied by Olemud S.A., a chemical plant situated in Buenos Aires, Argentina. The density, $\mathrm{pH}$, and the contents of glycerol, methanol, water, ashes, and MONG (Matter Organic Non-Glycerol) of the crude glycerol were measured.

The $\mathrm{pH}$ of the sample was determined using a $1 \mathrm{~g}$ of crude glycerol dissolved in $50 \mathrm{~mL}$ of distilled water and was measured with a digital pH-meter (Oakton pH 11 series, Vernon Hills, IL, USA) at room temperature.

Density was determined using a pycnometer at room temperature (ASTM 891-95). Glycerol and methanol content were determined using a Shimadzu GCMS-QP505A gas chromatograph (Shimadzu Corporation, Tokyo, Japan) equipped with a 50-m 19091S-001 HP PONA capillary column and FID detectors. Water content was measured using a Karl-Fisher titrator (SI Analytics TitroLine Alpha 20 Plus, Xylem Analytics, Weilheim, Germany) (ISO 2098-1972). Ash content was determined by burning $1 \mathrm{~g}$ of crude glycerol in a muffle at $750{ }^{\circ} \mathrm{C}$ for $3 \mathrm{~h}$ (ISO 2098-1972). MONG content was calculated as follows (ISO 2464-1973):

$$
\text { MONG }(w t . \%)=100-\text { glycerol content }(w t . \%)-\text { ash content }(w t . \%)-\text { water content }(w t . \%)
$$

\subsection{Catalytic Actitioy}

The activity tests were carried out with a BR-100 (Berghof, Eningen, Germany) high-pressure stainless-steel batch reactor of $100 \mathrm{~cm}^{3}$. The magnetic stirring was fixed at $1000 \mathrm{rpm}$ in order to ensure the kinetic control conditions.

The $\mathrm{Ni} / \gamma-\mathrm{Al}_{2} \mathrm{O}_{3}$ and $\mathrm{Ni} / \mathrm{CS}-\mathrm{P}$ catalysts were reduced ex situ in $\mathrm{H}_{2}$ flow and then cooled down to room temperature under hydrogen flow and immediately transferred to the reactor containing the glycerol. Finally, the reactor was closed, purged, and pressurized with $\mathrm{H}_{2}$ (Air Liquide, $99.99 \%$ ) up to the desired pressure. Afterwards, heating was started $\left(6^{\circ} \mathrm{C} \mathrm{min}^{-1}\right)$ and, when the reactor was at the desired temperature, the stirring began.

After reaction, the reactor was cooled down to ambient temperature. Gas samples were passed through a pipe with silica-gel so as to dry them and injected into a Shimadzu GC-8A gas chromatograph (Shimadzu Corporation, Tokyo, Japan) equipped with a thermal conductivity detector (TCD) and a Hayesep D 100-120 column operating isothermally at $40^{\circ} \mathrm{C}$. For the identification and quantification 
of gas samples, standards of $\mathrm{CO}, \mathrm{CO}_{2}$, and $\mathrm{CH}_{4}$ were used. Response factors for gas products were obtained using a calibration curve of the standards.

Once the gas samples were analyzed, the reactor was opened under hood, the catalyst was filtered and the liquid obtained was centrifuged and diluted in water (1:40). The liquid samples were injected into a Shimadzu GCMS-QP505A gas chromatograph equipped (Shimadzu Corporation, Tokyo, Japan) with a 50-m 19091S-001 HP PONA capillary column and FID detector. The identification of liquid products was performed by injecting aqueous solutions of the standards at $4 \mathrm{wt}$.\%. The following heating program was used: from $50{ }^{\circ} \mathrm{C}$ to $150{ }^{\circ} \mathrm{C}$ with a ramp of $10^{\circ} \mathrm{C} \mathrm{min}-1$, then from $150{ }^{\circ} \mathrm{C}$ to $220^{\circ} \mathrm{C}$ with a ramp of $40{ }^{\circ} \mathrm{C} \mathrm{min}^{-1}$ and then isothermally at $220^{\circ} \mathrm{C}$ up to the end of the analysis. The quantification was performed employing the integration of the areas of each compound multiplied by a response factor calculated according to the effective carbon number (ECAN) of each compound, as indicated by Scanlon and Willis [60].

The glycerol conversion $(X)$ was determined as follows:

$$
\text { Conversion }(\%)=\frac{\text { moles of consumed glycerol }}{\text { moles of initial glycerol }} \times 100 \%
$$

The selectivity to liquid products was defined as:

$$
\text { Selectivity to specific product }(\%)=\frac{\text { moles of carbon in specific product }}{3 \times \text { moles of consumed glycerol }} \times 100 \%
$$

The yield was defined as:

$$
\text { Yield to specific product }(\%)=\frac{\text { Selectivity to specific product } \times \text { Conversion }}{100}
$$

The carbon balance for all the tests was in the range between 93 and $97 \%$.

\section{Conclusions}

The aim of this study was to obtain 1-POH by the hydrogenolysis of crude glycerol using two consecutive reaction stages with Ni catalysts, so as to selectively obtain 1,2 PG in the first stage, which is the intermediate compound necessary to obtain 1-POH in the second stage.

With the $\mathrm{Ni} / \gamma-\mathrm{Al}_{2} \mathrm{O}_{3}$ catalyst, which presented small particles of metallic $\mathrm{Ni}$ interacting with the acid sites of the support, it was possible to obtain a complete conversion of crude glycerol with high selectivity to $1,2 \mathrm{PG}(87 \%)$ at $220^{\circ} \mathrm{C}$, whereas with the Ni/CS-P catalyst, the presence of AlPOx species and the $\mathrm{Ni}_{2} \mathrm{P}$ metallic phase supplied acidity to the catalyst, which promoted the $\mathrm{C}$-O bond cleavage reaction of the secondary carbon of 1,2-PG to obtain 1-POH with very high selectivity $(71 \%)$ at $260{ }^{\circ} \mathrm{C}$.

It was found that the employment of two consecutive reaction stages (first with $\mathrm{Ni} / \gamma-\mathrm{Al}_{2} \mathrm{O}_{3}$ at $220^{\circ} \mathrm{C}$ and then with $\mathrm{Ni} / \mathrm{CS}-\mathrm{P}$ at $260^{\circ} \mathrm{C}$ ) allows reaching levels of selectivity and a yield to 1-POH (79\%) comparable to noble metal-based catalysts.

Supplementary Materials: The following are available online at http://www.mdpi.com/2073-4344/10/6/615/s1, Synthesis of CS support, Figure S1: $\mathrm{N}_{2}$ adsorption-desorption isotherms for (a) CS-P and Ni/CS-P (b) $\gamma-\mathrm{Al}_{2} \mathrm{O}_{3}$ and $\mathrm{Ni} / \gamma-\mathrm{Al}_{2} \mathrm{O}_{3}$. Figure S2: Pore size distribution according to the $\mathrm{BJH}$ model for (a) CS-P and Ni/CS-P calculated from the adsorption branch, assuming slit-shape pore geometry (b) $\gamma-\mathrm{Al}_{2} \mathrm{O}_{3}$ and $\mathrm{Ni} / \gamma-\mathrm{Al}_{2} \mathrm{O}_{3}$ calculated from the desorption branch, assuming cylinder-shape pore geometry.

Author Contributions: M.N.G. and J.L.C. carried out all the experimental work which was conceived and designed with G.F.S. and F.P.; N.N.N. wrote the paper. All authors have read and approved the final manuscript.

Funding: This research was conducted with financial support from: “Consejo Nacional de Investigaciones Científicas y Técnicas" (CONICET-PIP 0065) and "Universidad Nacional de La Plata" (UNLP-I-248).

Conflicts of Interest: The authors declare no conflict of interest. 


\section{References}

1. Chheda, J.N.; Hubert, G.W.; Dumesic, J.A. Liquid-phase catalytic processing of biomass-derived oxygenated hydrocarbons to fuels and chemicals. Angew. Chem. Int. Edit. 2007, 46, 7164-7183. [CrossRef] [PubMed]

2. Zhou, C.H.; Beltrami, J.N.; Fan, Y.X.; Lu, G.Q. Chemoselective catalytic conversion of glycerol as a biorenewable source to valuable commodity chemicals. Chem. Soc. Rev. 2008, 37, 527-549. [CrossRef] [PubMed]

3. Hamzah, N.; Nordin, N.M.; Nadzri, A.H.A.; Nik, Y.A.; Kassim, M.B.; Yarmo, M.A. Enhanced activity of $\mathrm{Ru} / \mathrm{TiO}_{2}$ catalyst using bisupport, bentonite- $\mathrm{TiO}_{2}$ for hydrogenolysis of glycerol in aqueous media. Appl. Catal. A Gen. 2012, 419, 133-141. [CrossRef]

4. Salazar, J.B.; Falcone, D.D.; Pham, H.N.; Datye, A.K.; Passos, F.B.; Davis, R.J. Selective production of 1,2-propanediol by hydrogenolysis of glycerol over bimetallic $\mathrm{Ru}-\mathrm{Cu}$ nanoparticles supported on $\mathrm{TiO}_{2}$. Appl. Catal. A Gen. 2014, 482, 137-144. [CrossRef]

5. Lopez, A.; Aragón, J.A.; Hernández-Cortez, J.G.; Mosqueira, M.L.; Martínez-Palou, R. Study of hydrotalcite-supported transition metals as catalysts for crude glycerol hydrogenolysis. Mol. Catal. 2019, 468, 9-18. [CrossRef]

6. Li, X.; Xiang, M.; Wu, D. Hydrogenolysis of glycerol over bimetallic Cu-Ni catalysts supported on hierarchically porous SAPO-11 zeolite. Catal. Commun. 2019, 119, 170-175. [CrossRef]

7. Grabysch, T.; Muhler, M.; Peng, B.X. The kinetics of glycerol hydrodeoxygenation to 1,2-propanediol over $\mathrm{Cu} / \mathrm{ZrO}_{2}$ in the aqueous phase. Appl. Catal. A Gen. 2019, 576, 47-53. [CrossRef]

8. Varghese, J.J.; Cao, L.; Robertson, C.; Yang, Y.; Gladden, L.F.; Lapkin, A.A.; Mushrif, S.H. Synergistic Contribution of the Acidic Metal Oxide-Metal Couple and Solvent Environment in the Selective Hydrogenolysis of Glycerol: A Combined Experimental and Computational Study Using $\operatorname{ReO}_{x}$-Ir as the Catalyst. ACS Catal. 2019, 9, 485-503. [CrossRef]

9. Wan, X.; Zhang, Q.; Zhu, M.; Zhao, Y.; Liu, Y.; Zhou, C.; Yang, Y.; Cao, Y. Interface synergy between $\operatorname{IrO}_{x}$ and H-ZSM-5 in selective C-O hydrogenolysis of glycerol toward 1,3-propanediol. J. Catal. 2019, 375, 339-350. [CrossRef]

10. Liu, L.; Kawakami, S.; Nakagawa, Y.; Tamura, M.; Tomishige, K. Highly active iridium-rhenium catalyst condensed on silica support for hydrogenolysis of glycerol to 1,3-propanediol. Appl. Catal. B Environ. 2019, 256, 117775. [CrossRef]

11. Priya, S.S.; Kumar, V.P.; Kantam, M.L.; Bhargava, S.K.; Periasamy, S.; Chary, K.V.R. High Efficiency Conversion of Glycerol to 1,3-Propanediol Using a Novel Platinum-Tungsten Catalyst Supported on SBA-15. Ind. Eng. Chem. Res. 2015, 498, 88-98. [CrossRef]

12. Bhanuchander, P.; Priya, S.S.; Kumar, V.P.; Hussain, S.; Rajan, N.P.; Bhargava, S.K.; Chary, K.V.R. Direct Hydrogenolysis of Glycerol to Biopropanols over Metal Phosphate Supported Platinum Catalysts. Catal. Lett. 2017, 147, 845-855. [CrossRef]

13. Li, C.; He, B.; Ling, Y.; Tsang, C.-W.; Liang, C. Glycerol hydrogenolysis to $n$-propanol over Zr-Al composite oxide-supported Pt catalysts. Chin. J. Catal. 2018, 39, 1121-1128. [CrossRef]

14. Marinas, A.; Bruijnincx, P.; Ftouni, J.; Urbano, F.J.; Pinel, C. Sustainability metrics for a fossil- and renewable-based route for 1,2-propanediol production: A comparison. Catal. Today 2015, 239, 31-37. [CrossRef]

15. Zhu, S.; Zhu, Y.; Hao, S.; Zheng, H.; Mo, T.; Li, Y. One-step hydrogenolysis of glycerol to biopropanols over $\mathrm{Pt}_{-} \mathrm{H}_{4} \mathrm{SiW}_{12} \mathrm{O}_{40} / \mathrm{ZrO}_{2}$ catalysts. Green Chem. 2012, 14, 2607-2616. [CrossRef]

16. Dasari, M.A.; Kiatsimkul, P.-P.; Sutterlin, W.R.; Suppes, G.J. Low-pressure hydrogenolysis of glycerol to propylene glycol. Appl. Catal. A Gen. 2005, 281, 225-231. [CrossRef]

17. Miyazawa, T.; Kusunoki, Y.; Kunimori, K.; Tomishige, K. Glycerol conversion in the aqueous solution under hydrogen over $\mathrm{Ru} / \mathrm{C}+$ an ion-exchange resin and its reaction mechanism. J. Catal. 2006, 240, $213-221$. [CrossRef]

18. Furikado, I.; Miyazawa, T.; Koso, S.; Shimao, A.; Kunimori, K.; Tomishige, K. Catalytic performance of $\mathrm{Rh} / \mathrm{SiO}_{2}$ in glycerol reaction under hydrogen. Green Chem. 2007, 9, 582-588. [CrossRef]

19. Van Ryneveld, E.; Mahomed, A.S.; Van Heerden, P.S.; Friedrich, H.B. Direct Hydrogenolysis of Highly Concentrated Glycerol Solutions Over Supported Ru, Pd and Pt Catalyst Systems. Catal. Lett. 2011, 141, 958-967. [CrossRef]

20. Van Ryneveld, E.; Mahomed, A.S.; Van Heerden, P.S.; Green, M.J.; Friedrich, H.B. A catalytic route to lower alcohols from glycerol using Ni-supported catalysts. Green Chem. 2011, 13, 1819-1827. [CrossRef] 
21. Mai, C.T.Q.; Ng, F.T.T. Effect of Metals on the Hydrogenolysis of Glycerol to Higher Value Sustainable and Green Chemicals Using a Supported HSiW Catalyst. Org. Process. Res. Dev. 2016, 20, 1774-1780. [CrossRef]

22. Gallegos-Suarez, E.; Pérez-Cadenas, M.; Guerrero-Ruiz, A.; Rodriguez-Ramos, I.; Arcoya, A. Effect of the functional groups of carbon on the surface and catalytic properties of $\mathrm{Ru} / \mathrm{C}$ catalysts for hydrogenolysis of glycerol. Appl. Surf. Sci. 2013, 287, 108-116. [CrossRef]

23. Wang, M.; Yang, H.; Xie, Y.; Wu, X.; Chen, C.; Ma, W.; Dong, Q.; Hou, Z. Catalytic transformation of glycerol to 1-propanol by combining zirconium phosphate and supported Ru catalysts. RSC Adv. 2016, 6, 29769-29778. [CrossRef]

24. Delgado, S.N.; Yap, D.; Vivier, L.; Especel, C. Influence of the nature of the support on the catalytic properties of Pt-based catalysts for hydrogenolysis of glycerol. J. Mol. Catal. A Chem. 2013, 367, 89-98. [CrossRef]

25. Zhu, S.; Qiuc, Y.; Zhu, Y.; Hao, S.; Zheng, H.; Li, Y. Hydrogenolysis of glycerol to 1,3-propanediol over bifunctional catalysts containing Pt and heteropolyacids. Catal. Today 2013, 212, 120-126. [CrossRef]

26. Musolino, M.G.; Scarpino, L.A.; Mauriello, F.; Pietropaolo, R. Glycerol Hydrogenolysis Promoted by Supported Palladium Catalysts. ChemSusChem 2011, 4, 1143-1150. [CrossRef]

27. Li, Y.; Liu, H.; Ma, L.; He, D. Influence of Pd precursors and $\mathrm{Cl}$ addition on performance of Pd-Re catalysts in glycerol hydrogenolysis to propanediols. Appl. Catal. A Gen. 2016, 522, 13-20. [CrossRef]

28. Samudrala, S.P.; Bhattacharya, S. Toward the Sustainable Synthesis of Propanols from Renewable Glycerol over $\mathrm{MoO}_{3}-\mathrm{Al}_{2} \mathrm{O}_{3}$ Supported Palladium Catalysts. Catalysts 2018, 8, 385. [CrossRef]

29. Shozi, M.L.; Dasireddy, V.D.B.C.; Singh, S.; Govender, A.; Mohlala, P.; Friedrich, H.B. The effect of rhenium on the conversion of glycerol to mono-alcohols over nickel catalysts under continuous flow conditions. Sustain. Energy Fuels 2019, 3, 2038-2047. [CrossRef]

30. Shozi, M.L.; Dasireddy, V.D.B.C.; Singh, S.; Mohlala, P.; Morgan, D.J.; Friedrich, H.B. Hydrogenolysis of Glycerol to Monoalcohols over Supported Mo and W Catalysts. ACS Sustain. Chem. Eng. 2016, 4, 5752-5760. [CrossRef]

31. Lin, X.; Lv, Y.; Xi, Y.; Qu, Y.; Phillips, D.L.; Liu, C. Hydrogenolysis of Glycerol by the Combined Use of Zeolite and $\mathrm{Ni} / \mathrm{Al}_{2} \mathrm{O}_{3}$ as Catalysts: A Route for Achieving High Selectivity to 1-Propanol. Energy Fuels 2014, 28, 3345-3351. [CrossRef]

32. Balaraju, M.; Rekha, V.; Prabhavathi Devi, B.L.A.; Prasad, R.B.N.; Sai Prasad, P.S.; Lingaiah, N. Surface and structural properties of titania-supported Ru catalysts for hydrogenolysis of glycerol. Appl. Catal. A Gen. 2010, 384, 107-114. [CrossRef]

33. Rajkhowa, T.; Marin, G.B.; Thybaut, J.W. Quantifying the dominant factors in Cu catalyst deactivation during glycerol hydrogenolysis. J. Ind. Eng. Chem. 2017, 54, 270-277. [CrossRef]

34. Balaraju, M.; Jagadeeswaraiah, K.; Sai Prasad, P.S.; Lingaiah, N. Catalytic hydrogenolysis of biodiesel derived glycerol to 1,2-propanediol over Cu-MgO catalysts. Catal. Sci. Technol. 2012, 2, 1967-1976. [CrossRef]

35. Dam, J.T.; Kapteijn, F.; Djanashvili, K.; Hanefeld, U. Tuning selectivity of $\mathrm{Pt} / \mathrm{CaCO}_{3}$ in glycerol hydrogenolysis-A Design of Experiments approach. Catal. Commun. 2011, 13, 1-5. [CrossRef]

36. Gatti, M.N.; Mizrahi, M.D.; Ramallo-Lopez, J.M.; Pompeo, F.; Santori, G.F.; Nichio, N.N. Improvement of the catalytic activity of $\mathrm{Ni} / \mathrm{SiO}_{2}-\mathrm{C}$ by the modification of the support and $\mathrm{Zn}$ addition: Bio-propylene glycol from glycerol. Appl. Catal. A Gen. 2017, 548, 24-32. [CrossRef]

37. Gatti, M.N.; Pompeo, F.; Santori, G.F.; Nichio, N.N. Bio-propylene glycol by liquid phase hydrogenolysis of glycerol with $\mathrm{Ni} / \mathrm{SiO}_{2}-\mathrm{C}$ catalysts. Catal. Today 2017, 296, 26-34. [CrossRef]

38. Snaz, J.; Campelo, J.M.; Marinas, J.M. NMR characterization of synthetic and modified aluminum orthophosphates. J. Catal. 1991, 130, 642-652. [CrossRef]

39. Campelo, J.M.; Jaraba, M.; Luna, D.; Luque, R.; Marinas, J.M.; Romero, A.A. Effect of Phosphate Precursor and Organic Additives on the Structural and Catalytic Properties of Amorphous Mesoporous $\mathrm{AlPO}_{4}$ Materials. Chem. Mater. 2003, 15, 3352-3364. [CrossRef]

40. Raddi de Araujo, L.R.; Scofield, C.F.; Pastura, N.M.R.; Gonzalez, W.A. $\mathrm{H}_{3} \mathrm{PO}_{4} / \mathrm{Al}_{2} \mathrm{O}_{3}$ Catalysts: Characterization and Catalytic Evaluation of Oleic Acid Conversion to Biofuels and Biolubricant. Mater. Res. 2006, 9, 181-184. [CrossRef]

41. Gervasini, A.; Fenyvesi, J.; Auroux, A. Study of the acidic character of modified metal oxide surfaces using the test of isopropanol decomposition. Catal. Lett. 1997, 43, 219-228. [CrossRef]

42. Moffat, J.B.; Vetrivel, R.; Viswanathan, B. A model cluster study of the acid-base properties of phosphate catalysts. J. Mol. Catal. 1985, 30, 171-180. [CrossRef] 
43. Nahil, M.A.; Williams, P.T. Pore characteristics of activated carbons from the phosphoric acid chemical activation of cotton stalks. Biomass Bioenergy 2012, 37, 142-149. [CrossRef]

44. Yang, Y.; Ochoa-Hernández, C.; Pizarro, P.; De la Peña O’Shea, V.A.; Coronado, J.M.; Serrano, D.P. Influence of the $\mathrm{Ni} / \mathrm{P}$ ratio and metal loading on the performance of $\mathrm{Ni}_{x} \mathrm{P}_{y} / \mathrm{SBA}-15$ catalysts for the hydrodeoxygenation of methyl oleate. Fuel 2015, 144, 60-70. [CrossRef]

45. Cecilia, J.A.; Infantes-Molina, A.; Rodríguez-Castellón, E.; Jiménez-López, A. A novel method for preparing an active nickel phosphide catalyst for HDS of dibenzothiophene. J. Catal. 2009, 263, 4-15. [CrossRef]

46. Senseni, A.Z.; Meshkani, F.; Rezaei, M. Steam reforming of glycerol on mesoporous nanocrystalline $\mathrm{Ni}_{1} / \mathrm{Al}_{2} \mathrm{O}_{3}$ catalysts for $\mathrm{H}_{2}$ production. Int. J. Hydrogen Energy 2016, 41, 20137-20146. [CrossRef]

47. Wu, G.; Zhang, C.; Li, S.; Han, Z.; Wang, T.; Ma, X.; Gong, J. Hydrogen Production via Glycerol Steam Reforming over $\mathrm{Ni} / \mathrm{Al}_{2} \mathrm{O}_{3}$ : Influence of Nickel Precursors. ACS Sustain. Chem. Eng. 2013, 1, 1052-1062. [CrossRef]

48. Guo, J.; Lou, H.; Zhao, H.; Chai, D.; Zheng, X. Dry reforming of methane over nickel catalysts supported on magnesium aluminate spinels. Appl. Catal. A Gen. 2004, 273, 75-82. [CrossRef]

49. Marinoiu, A.; Ionita, G.; Gaspar, C.L.; Cobzaru, C.; Oprea, S. Glycerol hydrogenolysis to propylene glycol. React. Kinet. Catal. Lett. 2009, 97, 315-320. [CrossRef]

50. Menchavez, R.N.; Morra, M.J.; He, B.B. Co-Production of Ethanol and 1,2-Propanediol via Glycerol Hydrogenolysis Using Ni/Ce-Mg Catalysts: Effects of Catalyst Preparation and Reaction Conditions. Catalysts 2017, 7, 290. [CrossRef]

51. Long, W.; Hao, F.; Xiong, W.; Liu, P.; Luo, H. Modified sepiolite supported nickel and tungsten oxide catalysts for glycerol hydrogenolysis to 1,2-propanediol with high selectivity under mild conditions. React. Kinet. Mech. Catal. 2017, 122, 85-100. [CrossRef]

52. Perosa, A.; Tundo, P. Selective Hydrogenolysis of Glycerol with Raney Nickel. Ind. Eng. Chem. Res. 2005, 44, 8535-8537. [CrossRef]

53. Zhao, J.; Yu, W.; Chen, C.; Miao, H.; Ma, H.; Xu, J. Ni/NaX: A Bifunctional Efficient Catalyst for Selective Hydrogenolysis of Glycerol. Catal. Lett. 2010, 134, 184-189. [CrossRef]

54. Feng, J.; Wang, J.; Zhou, Y.; Fu, H.; Chen, H.; Li, X. Effect of Base Additives on the Selective Hydrogenolysis of Glycerol over $\mathrm{Ru} / \mathrm{TiO}_{2}$ Catalyst. Chem. Lett. 2007, 36, 1274-1275. [CrossRef]

55. Gandarias, I.; Arias, P.L.; Fernandez, S.G.; Requies, J.; Doukkali, M.E.; Guemez, M.B. Hydrogenolysis through catalytic transfer hydrogenation: Glycerol conversion to 1,2-propanediol. Catal. Today 2012, 195, $22-31$. [CrossRef]

56. Lee, Y.-K.; Oyama, S.T. Bifunctional nature of a $\mathrm{SiO}_{2}$-supported $\mathrm{Ni}_{2} \mathrm{P}$ catalyst for hydrotreating: EXAFS and FTIR studies. J. Catal. 2006, 239, 376-389. [CrossRef]

57. Sawhill, S.; Layman, K.; Vanwyk, D.; Engelhard, M.; Wang, C.; Bussell, M. Thiophene hydrodesulfurization over nickel phosphide catalysts: Effect of the precursor composition and support. J. Catal. 2005, 231, 300-313. [CrossRef]

58. Chen, J.; Shi, H.; Li, L.; Li, K. Deoxygenation of methyl laurate as a model compound to hydrocarbons on transition metal phosphide catalysts. Appl. Catal. B Environ. 2014, 144, 870-884. [CrossRef]

59. Zhao, S.; Li, M.; Chu, Y.; Chen, J. Hydroconversion of Methyl Laurate as a Model Compound to Hydrocarbons on Bifunctional $\mathrm{Ni}_{2} \mathrm{P} / \mathrm{SAPO}-11$ : Simultaneous Comparison with the Performance of Ni/SAPO-11. Energy Fuels 2014, 28, 7122-7132. [CrossRef]

60. Scanlon, J.T.; Willis, D.E. Calculation of Flame Ionization Detector Relative Response Factors Using the Effective Carbon Number Concept. J. Chromatogr. Sci. 1985, 23, 333-340. [CrossRef]

(C) 2020 by the authors. Licensee MDPI, Basel, Switzerland. This article is an open access article distributed under the terms and conditions of the Creative Commons Attribution (CC BY) license (http://creativecommons.org/licenses/by/4.0/). 